\title{
KARAKTERISTIK SURIMI YANG DIBUAT DARI HASIL PENCUCIAN DAGING IKAN CAKALANG (Katsuwonus pelamis L) DENGAN AIR DINGIN $\left( \pm 4^{\circ} \mathrm{C}\right)$
}

\author{
Farnis Saliada ${ }^{1}$, Hens Onibala ${ }^{2}$ dan Nurmeilita Taher $^{2}$ \\ ${ }^{1)}$ Mahasiswa pada Program Studi Teknologi Hasil Perikanan FPIK Unsrat Manado \\ ${ }^{2)}$ Staf pengajar pada Program Studi Teknologi Hasil Perikanan FPIK Unsrat Manado \\ Email: farnissaliada11@yahoo.co.id
}

\begin{abstract}
Pembuatan surimi melalui berbagai tahapan proses yang memiliki tujuan masing-masing yang berperan dalam menghasilkan surimi yang berkualitas baik. Penelitian ini bertujuan untuk mempelajari serta mengetahui pengaruh pencucian daging ikan cakalang (Katsuwonus pelamis L) dengan air dingin terhadap sifat kimia dan fisik surimi yang dihasilkan. Pengukuran kualitas surimi dilakukan dengan melakukan pengujian sifat fungsional surimi baik dengan cara fisik maupun kimia pada surimi yang telah dilakukan perlakuan. Dalam penelitian ini dilakukan uji lipat (folding test), uji tekstur dan analisa kadar lemak. Rancangan percobaan yang digunakan adalah rancangan acak lengkap (RAL). Nilai rata-rata uji lipat secara berturut-turut dari perlakuan kontrol sampai lama pencucian 4 menit adalah 2,2, 2,6, 3, 3,8 dan 4,6. Dimana semakin lama waktu pencucian cenderung semakin meningkatkan. Nilai rata-rata uji tekstur secara berturut-turut dari perlakuan kontrol sampai lama pencucian 4 menit adalah 3, 3,8, 4,4, 5,1 dan 5,9. Dimana semakin lama waktu pencucian cenderung semakin meningkatkan nilainya. Hasil analisa kadar lemak surimi menunjukkan bahwa semakin lama pencucian dengan air dingin nilai kadar lemak surimi akan semakin menurun. Nilainya berkisar antara $0,47 \%$ pada lama pencucian air dingin 4 menit sampai $1,13 \%$ pada perlakuan kontrol (pencucian dengan air biasa).
\end{abstract}

Kata Kunci: Ikan Cakalang, Surimi, Uji Lipat, Uji Tekstur, Analisa Lemak.

\section{PENDAHULUAN}

Sektor perikanan dan peternakan merupakan andalan utama sumber pangan dan gizi bagi masyarakat Indonesia.Ikan selain merupakan sumber protein juga diakui sebagai functional food yang mempunyai arti penting bagi kesehatan karena mengandung asam lemak tidak jenuh berantai panjang (terutama yang tergolong asam lemak omega-3, vitamin serta makro dan mikro mineral). Dibanding negara lain sumbang-sumbang perikanan dalam penyediaan protein di Indonesia termasuk besar, yakni 55 persen. Diperkirakan angka konsumsi ikan secara aktual berada dibawah angka kesediaan tersebut, karena masih tingginya angka susut hasil baik kuantitas, kualitas, maupun nilai gizinya (Heruwati, 2002).

Surimi merupakan istilah dalam bahasa Jepang untuk daging lumat dan jaringan ikan yang dicuci. Produksi surimi secara komersial dibuat dengan alat pemisah mekanik untuk memisahkan daging lumat ikan dari tulang dan kulit, diikuti dengan pencucian (sampai dengan tiga kali) dengan air atau larutan garam. Proses pencucian menghilangkan sebagian besar komponen yang larut dalam air, darah (pigmen), penyebab bau dan lemak. Setelah pencucian terakhir, daging lumat diperas dan dicampur dengan cryoprotectant yang tepat untuk mencegah denaturasi protein selama penyimpanan beku, Nakai dan Modler (2000) dalam Astuti (2009)

\section{METODOLOGI PENELITIAN}

Metode yang digunakan dalam penelitian ini adalah metode deskriftif yaitu mengumpulkan data dan fakta yang tersedia di lapangan melalui pencatatan dan pengamatan secara terperinci dan sistematik kemudian dilakukan analisa data kualitatif dan data kuantitatif.

\section{Tempat dan Waktu Penelitian}

Penelitian ini dilaksanakan di Laboratorium Teknologi Penanganan dan Pengolahan Hasil Perikanan di Fakultas Perikanan dan Ilmu Kelautan, Universitas Sam Ratulangi Manado dan Laboratorium Balai Riset dan Standarisasi Industri Manado.Waktu pelaksanaan penelitian mulai tanggal 22 Juli sampai 1 Desember 2016. 


\section{Alat dan Bahan}

Alat-alat yang digunakan adalah kain saring, baskom, selongsong dengan bahan stainless steel, blender, termometer, top watch, timbangan, panci, gelas ukur, telenan, kompor, sendok, pisau, plastik. Sedangkan peralatan untuk analisa kimia (uji lemak) adalah Kertas saring, desikator, soxhlet, oven, labu lemak, timbangan analitik.

Bahan yang di gunakan dalam penelitian ini adalah Ikan cakalang (Katsuwonus pelamis L), es dan garam. Sedangkan bahan yang digunakan untuk uji lemak adalah dieter.

\section{Perlakuan}

Data yang diperoleh dianalisa dengan menggunakan Rancangan percobaan. Rancangan percobaan yang digunakan dalam penelitian ini yaitu Rancangan Acak Lengkap (RAL) dengan 2 kali ulangan dan 4 perlakuan, dimana lama pencucian sebagai faktor perlakuan.

Analisis fisik dilakukan terhadap hasil pengujian sensori dengan metode uji mutu sensori menggunakan uji Kruskal Wallis (Walpole, 1993) dengan rumus sebagai berikut:

Keterangan :

$$
\begin{gathered}
H=\left[\frac{12}{n(n+1)} \sum \frac{R_{i}^{2}}{n_{i}}\right]-3(n+1) \\
H^{\prime}=\frac{H}{\text { Pembagi }} \\
\text { Pembagi }=1-\frac{\ddagger^{\prime \prime} T}{(n-1) n(n-1)}
\end{gathered}
$$

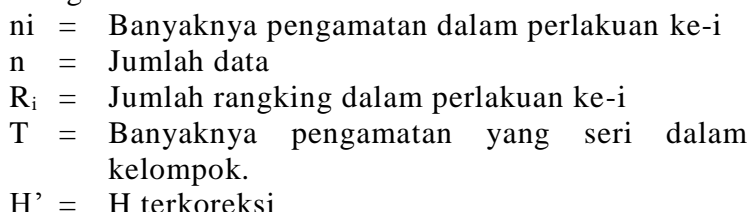

\section{Tata Laksana Penelitian} Tahapan Penelitian

Pengambilan sampel ikan cakalang dari tempat pelelangan ikan (TPI) Pasar Bersehati Manado sebanyak 5 ekor. Kemudian ikan-ikan tersebut diisi dalam cool box, perbandingan ikan dengan es adalah 1:2. Ikan yang ada di cool box dikeluarkan satu persatu untuk dibersihkan dengan cara membuang kepala, isi perut, ekor, tulang-tulang, dan kulit, sehingga diperoleh daging ikan. Kemudian daging ikan dicuci bersih, pencucian bertujuan untuk menghilangkan darah yang ada pada daging ikan. Daging ikan yang sudah dicuci kemudian dipotong kecil-kecil, pemotongan ini bertujuan untuk mempermudah pada saat proses penggilingan. Kemudian daging ikan dihaluskan dengan menggunakan blender sehingga didapat daging lumat halus menyerupai bentuk pasta. Pasta yang dihasilkan dicuci dengan air dingin, dengan suhu air dingin $\left( \pm 4^{\circ} \mathrm{C}\right)$, dengan lama pencucian sebagai perlakuan yaitu: 1, 2, 3 dan 4 menit. Dalam penelitian ini juga dilakukan Analisis kimia pada surimi meliputi analisa lemak. Surimi yang telah diproses kemudian dikemas dalam kemasan plastik dan dibekukan dalam freezer selama 1 malam. Pembuatan gel ikan yaitu surimi diambil sekitar 100 gram, ditambahkan $3 \%$ garam dan diadon selama 5 menit. Kemudian adonan yang sudah jadi diisikan ke dalam selongsong stainless steel berdiameter 30 $\mathrm{mm}$. Perebusan dilakukan secara bertahap yaitu pada suhu $40^{\circ} \mathrm{C}$ selama 20 menit dan pada suhu $90^{\circ} \mathrm{C}$ selama 20 menit. Dalam penelitian juga dilakukan uji fisik pada gel ikan yang dibuat dari surimi, uji fisik yang digunakan yaitu uji lipat (folding test) uji tekstur.

\section{Diagram alir prosedur Penelitian} Ikan cakalang segar

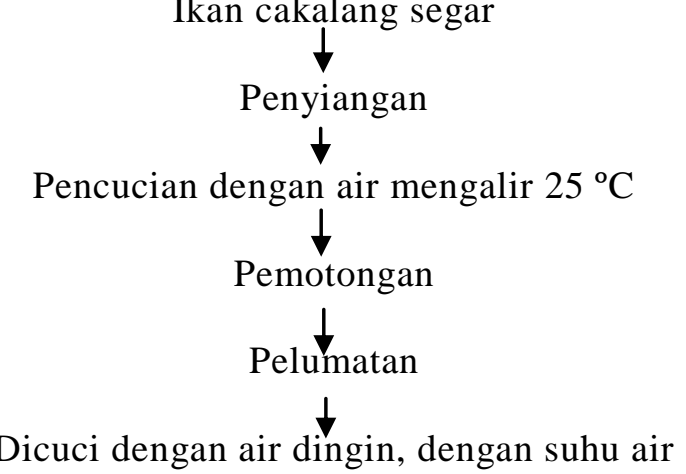
dingin $\left( \pm 4^{\circ} \mathrm{C}\right)$, dengan lama pencucian sebagai perlakuan yaitu: 1, 2, 3 dan 4 menit.

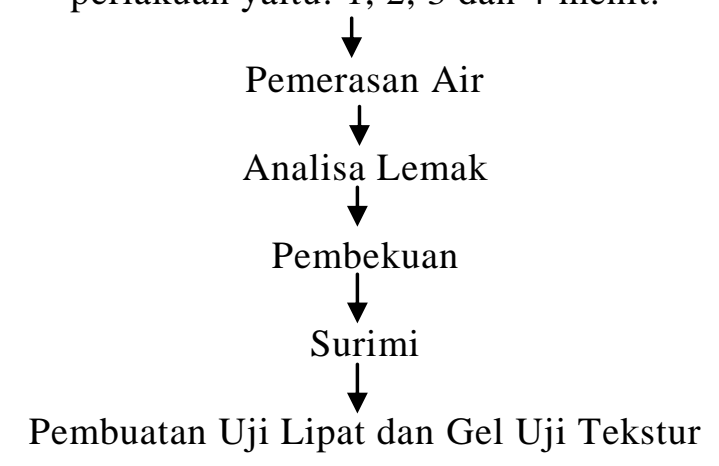

\section{HASIL DAN PEMBAHASAN}

\section{Uji Lipat (folding test)}

Uji lipat merupakan salah satu pengujian terhadap mutu gel ikan. Pengamatan uji lipat dilakukan oleh 15 orang panelis. Pengujian dilakukan dengan cara melipat sampel menjadi seperempat lingkaran. 
Tingkatan mutu yang digunakan adalah skala 19. Uji lipat cocok untuk membedakan gel yang bermutu tinggi dan bermutu rendah, tetapi tidak bisa membedakan antara gel yang bermutu baik dan bermutu sangat baik. Lanier (1992) dalam Oktaviani (2012).

Nilai rata-rata uji lipat secara berturutturut dari perlakuan kontrol sampai lama pencucian 4 menit adalah 2,2, 2,6, 3, 3,8 dan 4,6. Dimana semakin lama waktu pencucian cenderung semakin meningkatkan nilainya. Hasil uji lipat ini berkaitan langsung dengan tekstur gel, terutama kekuatan gel.Semakin baik hasil uji lipat, mutu gel surimi yang dihasilkan semakin baik. Uji lipat gel ini diduga dipengaruhi oleh proses pencucian yang dapat meningkatkan kekuatan gel dengan semakin pekatnya protein miofibril (Santoso, $d k k$. 1997) menyatakan bahwa semakin baik hasil uji lipat (makin sukar retak), maka mutu gel ikan yang dihasilkan pun semakin baik.

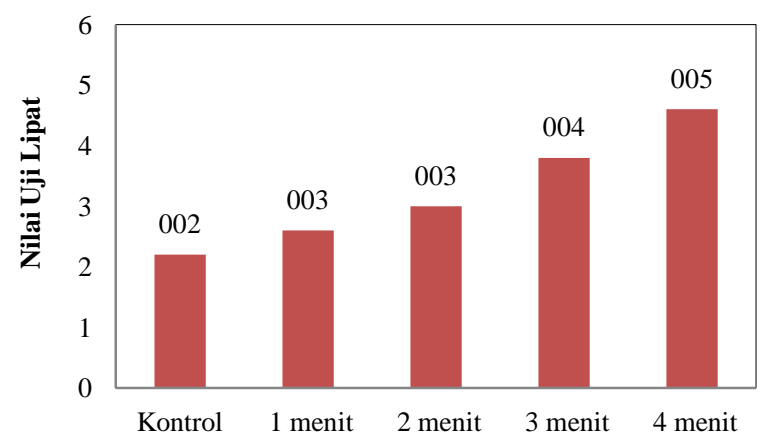

Gambar 1. Histogram Nilai Uji Lipat.

\section{Uji Tekstur}

Uji tekstur merupakan salah satu pengujian terhadap mutu gel surimi. Pengamatan uji tekstur dilakukan oleh 15 orang panelis. Pengujian dilakukan dengan cara menekan sampel dengan jari. Tingkatan mutu yang digunakan adalah skala 1-9.

Nilai rata-rata uji tekstur secara berturut-turut dari perlakuan kontrol sampai lama pencucian 4 menit adalah 3, 3,8, 4,46, 5,13 dan 5,93. Dimana semakin lama waktu pencucian cenderung semakin meningkatkan nilainya. Tekstur gel ikan yang dihasilkan diduga dipengaruhi oleh frekwensi pencucian dalam pembuatan surimi. Pencucian dapat meningkatkan kekuatan gel. Frekwensi pencucian dapat menghilangkan sarkoplasma yang dapat menghambat pembentukan gel dan melarutkan protein miofibril sehingga membentuk selaktomiosin, Astawan, $d k k$. (1996) dalam Oktaviani (2012).

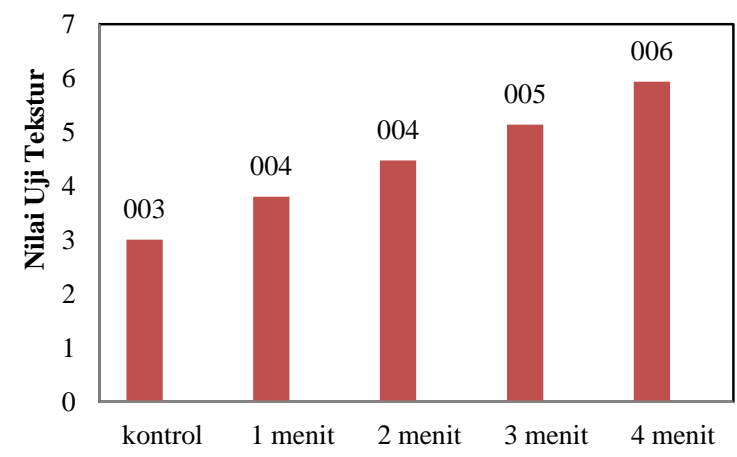

Gambar 2. Histogram Nilai Uji Tekstur

\section{Kadar Lemak}

Hasil analisa kadar lemak surimi menunjukan bahwa semakin lama pencucian dengan air dingin nilai kadar lemak surimi akan semakin menurun. Nilainya berkisar antara $0,47 \%$ pada lama pencucian air dingin 4 menit sampai $1,13 \%$ pada perlakuan kontrol (pencucian dengan air biasa). Hasil analisis ststistik ragam pada á $=0,05$ menunjukan bahwa perlakuan lama pencucian memberikan pengaruh tidak nyata terhadap kadar lemak surimi.

Tabel 1. Kadar lemak ikan Cakalang selama proses pembuatan surimi.

\begin{tabular}{cccccc}
\hline \multirow{2}{*}{ Ulangan } & \multicolumn{5}{c}{ Kadar Lemak (\%) } \\
\cline { 2 - 6 } & Kontrol & 1 Menit & 2 Menit & 3 Menit & 4 Menit \\
\hline $\mathbf{1}$ & 0.69 & 0.56 & 0.26 & 0.32 & 0.15 \\
$\mathbf{2}$ & 0.44 & 0.59 & 0.25 & 0.52 & 0.32 \\
\hline$\sum$ & $\mathbf{1 . 1 3}$ & $\mathbf{1 . 1 5}$ & $\mathbf{0 . 5 1}$ & $\mathbf{0 . 8 4}$ & $\mathbf{0 . 4 7}$ \\
\hline Rata-rata & 0.56 & 0.57 & 0.25 & 0.42 & 0.23 \\
\hline
\end{tabular}

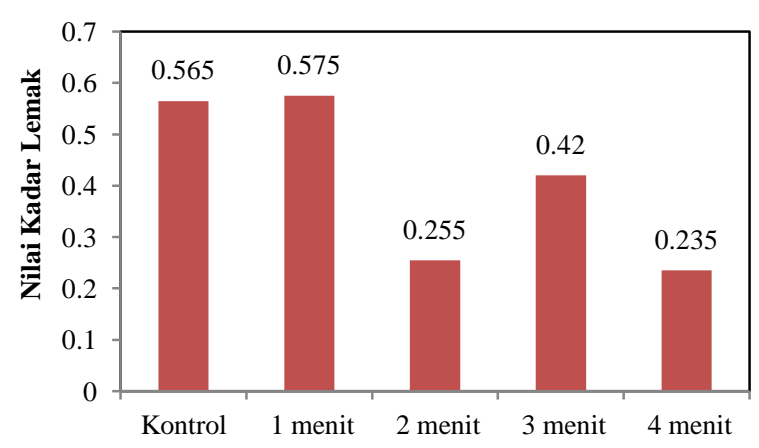

Gambar 3. Histogram Nilai Kadar Lemak.

\section{KESIMPULAN DAN SARAN}

\section{Kesimpulan}

Daging ikan cakalang ternyata dapat diolah menjadi surimi sebagai produk intermediet walaupun dibandingkan dengan 
jenis daging ikan lain nilai kekuatan gelnya cenderung lebih rendah.

Hasil analisis secara kimia menunjukan bahwa proses pencucian daging ikan cakalang dengan berbagai perlakuan lama pencucian memberikan pengaruh tidak nyata terhadap kadar lemak.

Hasil uji fisik gel ikan menunjukan bahwa proses pencucian daging ikan cakalang dengan berbagai perlakuan lama pencucian memberikan pengaruh tidak nyata terhadap uji lipat dan uji tekstur.

Secara keseluruhan dapat disimpulkan bahwa lama perendaman 4 menit merupakan waktu terbaik dalam pembentukan gel ikan karena memiliki nilai uji lipat tertinggi 4,6 dan uji tekstur 5,93. Uji kimia surimi menghasilkan nilai kadar lemak 0,23

\section{Saran}

Dari penelitian yang telah dilakukan, perlu dilakukan penelitian lanjutan. Untuk waktu pencucian, durasinya bisa dilakukan dengan waktu lebih lama, agar mendapatkan hasil yang lebih baik.

\section{DAFTAR PUSTAKA}

Astuti E. F. 2009. Pengaruh Jenis Tepung Dan Cara Pemasakan Terhadap Mutu Bakso Dari Surimi Ikan Hasil Tangkap Sampingan (HTS). Skripsi. FPIK IPB. Bogor

Heruwati E. S. 2002. Pengolahan Ikan Secara Tradisional: Prospek dan Peluang Pengembangan. Jurnal Litbang Pertanian. Pusat Riset Pengolahan Produk dan Sosial Ekonomi Kelautan Perikanan. Jakarta.

Oktaviani, D. 2012. Karakteristik Fisika Kimia Gel Dan Bakso Dari Surimi Ikan Layaran (Istiophorus sp.) “Skripsi' FPIK IPB. Bogor

Santoso J, Trilaksani W, Nurjanah, Nurhayati T. 1997. Perbaikan Mutu Gel Ikan Mas (Cyprinus carpio) Melalui Modifikasi Proses. Lembaga Penelitian IPB. Bogor.

Walpole R. E. (Eds) 1993. Pengantar Statistika Statistika. Jakarta. Gramedia Pustaka Utama. 